\title{
Optimizing operational parameters for the enzymatic production of furandicarboxylic acid building block
}

\author{
María Isabel Sánchez-Ruiz, Angel T. Martínez (1) and Ana Serrano*
}

\begin{abstract}
Background: 2,5-Furandicarboxylic acid (FDCA) is a precursor for green plastics due to its structural similarity to terephthalic acid, a common precursor of oil-derived polymers, and its potential production from sugars obtained from plant biomass. Hydroxymethylfurfural oxidase (HMFO) has been reported as a promising biocatalyst for FDCA production since it can convert bio-based 5-hydroxymethylfurfural (HMF) into FDCA building block. This three-step oxidation reaction occurs through the diformylfuran and 2,5-formylfurancarboxylic acid (FFCA) intermediates. Several efforts have been made for the development of HMFO variants that increase FDCA yields by improving their activities over the reaction intermediates. However, there is still limited insight into how operational conditions can influence these enzymatic reactions. The setup of optimal reaction conditions would enable to understand potential problems hampering the effective industrial production of this bioplastic precursor using HMFO as biocatalyst.
\end{abstract}

Results: In this work, several parameters affecting the performance of Methylovorus sp HMFO oxidizing HMF have been analyzed for the wild-type enzyme, and its V367R and W466F single variants, V367R/W466F double variant, and I73V/H74Y/G356H/V367R/T414K/A419Y/A435E/W466F (8BxHMFO) octuple variant. Our results show how the oxidation of HMF by HMFO enzymes is highly influenced by $\mathrm{pH}$, with different optimal $\mathrm{pH}$ values for the different improved variants. Moreover, the enzymes are not stable at high hydrogen peroxide concentrations and their activity is inhibited by the FFCA intermediate in a pH-dependent way. These limitations can be efficiently overcome with the addition of catalase to the reaction medium, which removes the hydrogen peroxide formed during the oxidations, and the controlled dosage of the substrate to limit the amount of FFCA accumulated in the reaction. The different behavior of wild-type HMFO and its variants against $\mathrm{pH}$, hydrogen peroxide and FFCA highlights the importance of considering each variant as an individual enzyme with its own operational conditions for an eventual industrial FDCA production.

Conclusions: This work provides information of those parameters that condition a high production of FDCA by HMFO. Unraveling these factors allowed to increase the FDCA yields by using the most stable enzymes at their optimal pH for HMF oxidation, removing the peroxide with catalase, and avoiding FFCA accumulation by controlling substrate and/or enzyme concentration. These above findings will be useful when planning a future scale-up of these conversions and will provide new viewpoints for the design of HMFO variants that render a more effective performance during HMF conversion into FDCA.

*Correspondence: atmartinez@cib.csic.es; anaserra1979@gmail.com Centro de Investigaciones Biológicas "Margarita Salas" (CIB), CSIC, Ramiro de Maeztu 9, 28040 Madrid, Spain original author(s) and the source, provide a link to the Creative Commons licence, and indicate if changes were made. The images or other third party material in this article are included in the article's Creative Commons licence, unless indicated otherwise in a credit line to the material. If material is not included in the article's Creative Commons licence and your intended use is not permitted by statutory regulation or exceeds the permitted use, you will need to obtain permission directly from the copyright holder. To view a copy of this licence, visit http://creativecommons.org/licenses/by/4.0/. The Creative Commons Public Domain Dedication waiver (http://creativeco mmons.org/publicdomain/zero/1.0/) applies to the data made available in this article, unless otherwise stated in a credit line to the data. 
Keywords: Enzymatic catalysis, Hydroxymethylfurfural oxidase, Catalase, Enzyme engineering, 2,5-Furandicarboxylic acid product, 5-Formylfurancarboxylic acid intermediate, Reaction pH, Hydrogen peroxide by-product, Enzyme inhibition, Reaction optimization

\section{Background}

A 2017 global analysis estimated in over 8000 million tons the total amount of virgin plastics produced by the petrochemical industry [1]. This production generated high greenhouse gas emissions from non-renewable fossil resources, and caused both land and water pollution due to limited recycling. Substitution of these oil-based plastics with biodegradable polymers derived from renewable raw materials is thus necessary for the development of a sustainable bio-economy [2]. One of the most promising bio-based plastic polymers is poly(ethylene-2,5-furandicarboxylate) (PEF) [3, 4]. PEF can be used as a green substitute for conventional poly(ethylene-terephthalate) (PET) due to its similar, or even better, properties $[5,6]$. The interest of PEF lies in its composition, as it is formed by esterification of ethylene glycol with the renewable building block 2,5-furandicarboxylic acid (FDCA), which can be obtained from sugars derived from lignocellulosic biomass $[7,8]$.

The processes for FDCA production from lignocellulosic feedstocks usually comprise two steps. First, monosaccharides (generally fructose) derived from plant polysaccharides are dehydrated to form the platform chemical 5-hydroxymethylfurfural (HMF). Second, HMF is converted into FDCA through three consecutive oxidation steps, involving its alcohol and aldehyde groups, that firstly yield diformylfuran (DFF) or hydroxymethylfurancarboxylic acid (HMFCA), respectively, and then formylfurancarboxylic acid (FFCA) as reaction intermediates (Fig. 1) [9, 10]. Different chemical methods have been described for HMF conversion into FDCA, however, they typically lead to low yields and selectivities, and require high temperatures and pressures and the use of metal salts and organic solvents that render the process expensive and polluting $[11,12]$. Thus, in the context of green industry, biocatalytic alternatives to these processes are highly interesting, since the reactions can be performed under environmentally-friendly conditions using mild and biodegradable catalysts [13].

A variety of studies have been performed for the production of FDCA using both enzymatic and whole-cell catalysis $[8,14,15]$. With this aim, several oxidative

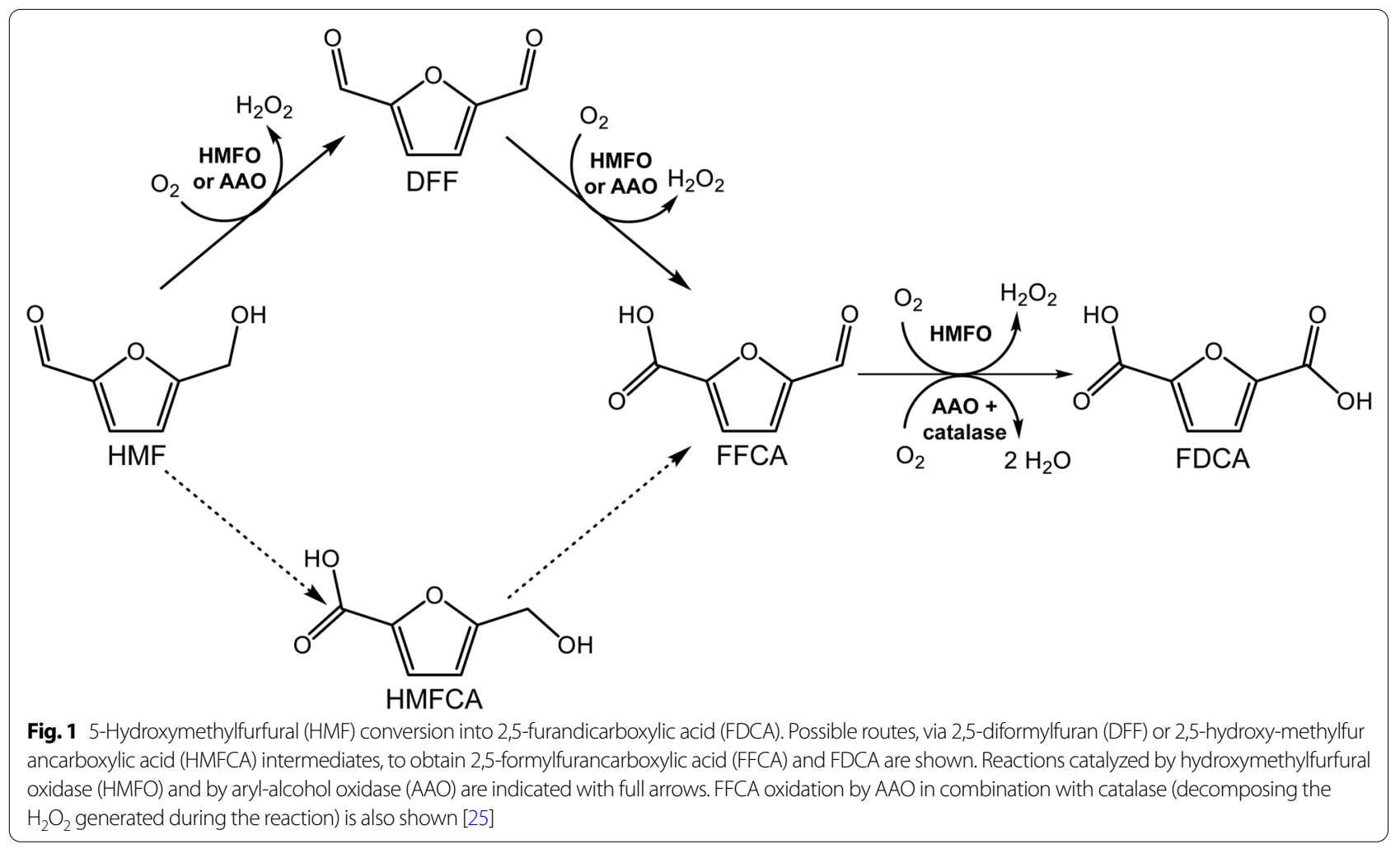


enzymes have been suggested for the production of FDCA from HMF. However, because most of them are limited to either aldehyde or alcohol oxidation, multienzymatic cascades are usually required to complete the reaction [16-22]. This often limits the overall yield of the process since a consensus between the operational conditions of each enzyme needs to be established. Up to now, only two enzyme types-hydroxymethylfurfural oxidase (HMFO) from Methylovorus sp MP688 [23] and Pseudomonas species [24], and aryl-alcohol oxidase (AAO) from Pleurotus eryngii [25]-have been reported to carry out the three oxidation steps for HMF conversion into FDCA. Both are FAD-containing enzymes of the glucose-methanol-choline oxidase/dehydrogenase (GMC) superfamily [26] with activity on both primary aryl alcohols and hydrated aryl aldehydes. Due to their preference for alcohol substrates, they oxidize HMF into FDCA through the DFF and FFCA intermediates (Fig. 1). However, several characteristics would confer HMFO advantages for the industrial production of FDCA, compared to AAO. First, the bacterial HMFO can be easily overexpressed in Escherichia coli in a soluble active form [24,27], in contrast to fungal AAO that is typically produced as inclusion bodies in E. coli hosts and thus requires in vitro activation [28] (a time and money consuming process). Nevertheless, the soluble production of P. eryngii AAO using Komagataella pastoris (syn. Pichia pastoris) has been recently reported [29], although a more detailed analysis of the effect of its hyper-glycosylation on furfural oxidation is required. Second, the oxidation of FFCA, which constitutes the limiting step for the enzymatic production of FDCA from HMF, is more efficient for HMFO, since FFCA oxidation by AAO requires long reaction times and is highly inhibited by $\mathrm{H}_{2} \mathrm{O}_{2}$ [25]. In addition, HMFO production has been recently upscaled in a cost-effective bioreactor process [30], a crucial factor when considering its industrial application as a biocatalyst.

Due to its promising use for FDCA production, structural and mutagenic studies of the active site of Methylovorus HMFO by Dijkman et al. [31] led to identify the V367R, W466F and V367R/W466F variants as improved biocatalysts. These engineered enzymes perform a faster oxidation of FFCA, the rate-limiting reaction in HMF conversion, than the wild type (WT) enzyme. Moreover, by combining computational prediction and gene shuffling approaches, a multiple variant (8BxHMFO) with eight mutations (I73V/H74Y/G356H/V367R/T414K/ A419Y/A435E/W466F) was designed in subsequent studies as a more robust and stable enzyme during catalysis [32]. However, studies on the operational conditions for HMF oxidation into FDCA (using the above HMFO WT and derived variants) are scarce, and a focused analysis of their behavior during these conversions is needed before proposing them as industrial biocatalysts.

In this work, a comprehensive study on different parameters that could affect the performance of Methylovorus $\mathrm{HMFO}$ in the production of FDCA from HMF has been carried out for HMFO WT and its V367R, W466F, V367R/W466F and 8BxHMFO variants. Thus, the effect of $\mathrm{pH}$ on enzyme stability and activity, the inhibition by reaction product and by-product, the initial substrate concentration, the cofactor dependency, and the oxygen reactivity have been evaluated. This allowed to optimize the operational conditions for each enzyme variant, and to bring closer the application of the most relevant candidates for the enzymatic production of FDCA at an industrial scale. The information obtained will provide useful insights for future studies with HMFO-type enzymes, and will also contribute to the development of new HMFO variants for enhanced FDCA production from HMF.

\section{Results and discussion \\ Effect of $\mathrm{pH}$ on FDCA production}

First, the pH stability of the enzymes was analyzed by measuring their residual activity (on the standard substrate vanillyl alcohol) after $72 \mathrm{~h}$ of incubation in the range of $\mathrm{pH}$ 6.5-9.0 (Fig. 2a) since it has been reported that the Methylovorus enzyme and other HMFOs totally lost their activity after $24 \mathrm{~h}$ out of this range [24]. HMFO $\mathrm{WT}$ and $8 \mathrm{BxHMFO}$ remained stable in the full $\mathrm{pH}$ range, keeping $70-80 \%$ of their initial activity. V367R retained $\sim 80 \%$ of its activity between $\mathrm{pH} 6.5$ and 8.0 , and $\sim 40 \%$ at $\mathrm{pH}$ 9.0. Similar behaviors were observed for the W466F and V367R/W466F variants, as both remained more active at $\mathrm{pH}$ 7.5-8.0, but they lost most of the activity at $\mathrm{pH}$ 9.0. The V367R/W466F variant showed to be particularly unstable, as it lost $>50 \%$ of its activity at all the $\mathrm{pH}$ values tested.

A high dependence on $\mathrm{pH}$ has been recently reported for FDCA production by a WT HMFO [24]. Thus, this possible effect was evaluated here for the different variants. With this purpose, 24-h enzymatic reactions were performed at $28^{\circ} \mathrm{C}$ in $50 \mathrm{mM} \mathrm{NaPi}, \mathrm{pH} 6.5$, or in $50 \mathrm{mM}$ Tris/ $\mathrm{HCl}, \mathrm{pH}$ 7.5-9.0, and the production of FDCA from $1.5 \mathrm{mM}$ HMF or FFCA was analyzed by high-performance liquid chromatography (HPLC) after $24 \mathrm{~h}$ (Fig. 2c and $\mathrm{d}$, respectively). For the $8 \mathrm{BxHMFO}$ variant, yields after 4 -h reaction were considered, since at $24 \mathrm{~h}$ total conversion was observed at all the $\mathrm{pH}$ values. For HMFO WT the optimal pH for FDCA production was 6.5. Surprisingly, all $\mathrm{HMFO}$ variants shifted this optimum to $\mathrm{pH}$ 8.0-9.0 for the oxidation of both substrates. The $\mathrm{pH}$ values in which the maximal half-lives were observed during 

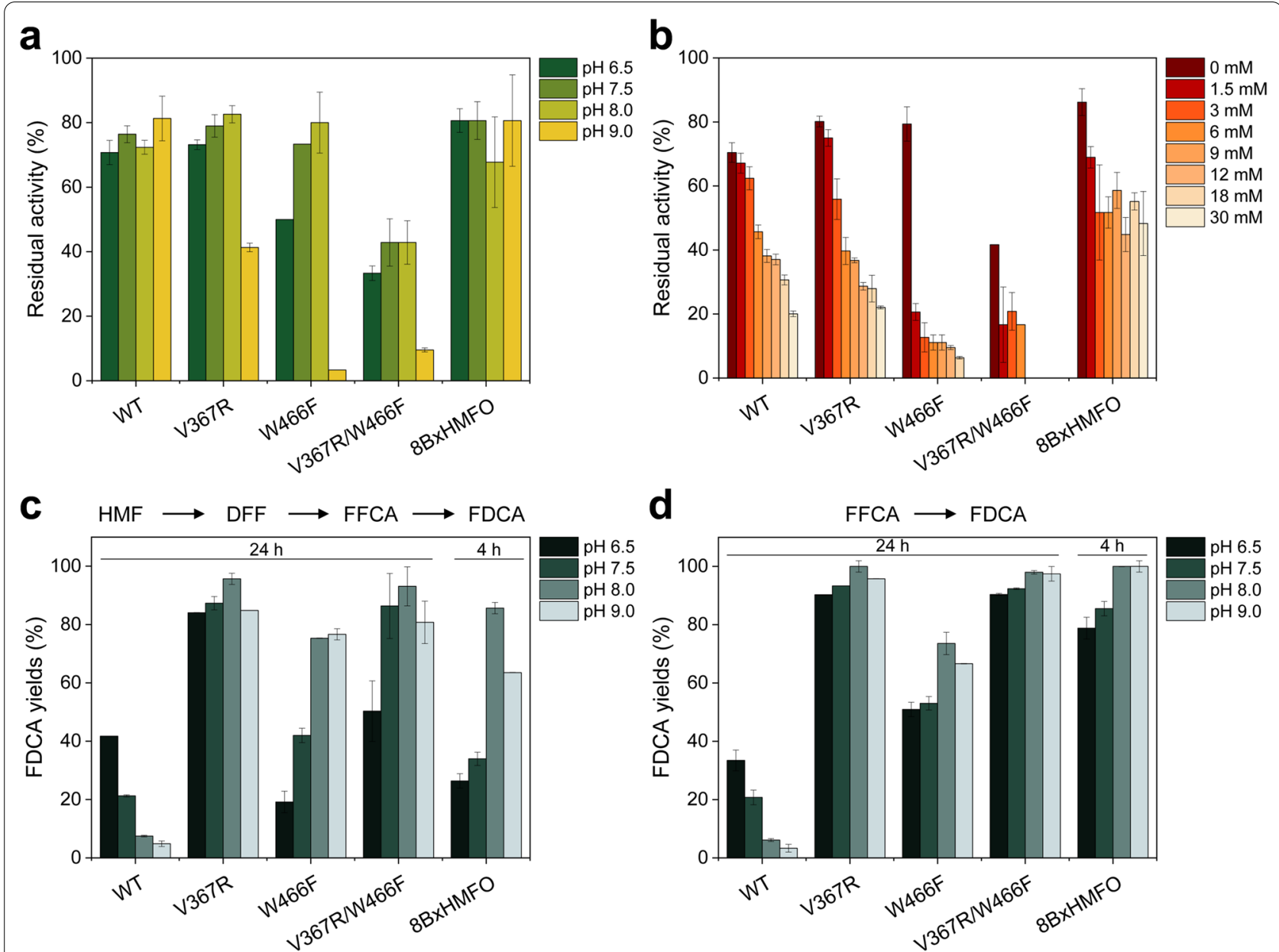

Fig. 2 Effect of $\mathrm{pH}(\mathbf{a})$ and $\mathrm{H}_{2} \mathrm{O}_{2}$ (b) on HMFO stability, and influence of $\mathrm{pH}$ on FDCA production from $\mathrm{HMF}$ (c) and FFCA (d). a pH stability as shown by residual activities after 72 -h incubation of the enzymes in $100 \mathrm{mM} \mathrm{B} \& \mathrm{R}$ buffer ( $\mathrm{pH}$ 6.5-9) at $25^{\circ} \mathrm{C} . \mathbf{b} \mathrm{H}_{2} \mathrm{O}_{2}$ stability as shown by residual activities after 72-h incubation of the enzymes with increasing amounts of $\mathrm{H}_{2} \mathrm{O}_{2}(0-30 \mathrm{mM})$ in $50 \mathrm{mM}$ Tris/ $\mathrm{HCl}$, pH 7.5. The residual activities were measured with vanillyl alcohol as substrate. Percentages of FDCA (referred to initial substrate concentration) in $\mathbf{c}$ and $\mathbf{d}$ are shown after 24-h reaction of HMF or FFCA, respectively, with the HMFO WT and variants (4-h reaction with 8BxHMFO) at different pH values. The reactions were performed at $28^{\circ} \mathrm{C}$ and $180 \mathrm{rpm}$ shaking, using $1.5 \mathrm{mM}$ substrate, and $2.5 \mu \mathrm{M}$ enzyme, in $50 \mathrm{mM} \mathrm{NaPi}(\mathrm{pH}$ 6.5) or Tris/ $\mathrm{HCl}$ (pH 7.5, 8.0 and 9.0). Mean and standard deviation values from triplicate experiments are shown

HMF and FFCA conversion (Table 1) coincided with the $\mathrm{pH}$ at which each enzyme achieved the highest FDCA yields in 24-h reactions (Fig. 2c and d).

\section{Effect of $\mathrm{H}_{2} \mathrm{O}_{2}$ byproduct on FDCA production}

In the oxidation of HMF to FDCA, three equivalents of $\mathrm{H}_{2} \mathrm{O}_{2}$ are produced by HMFO since the reaction takes place through two furfural intermediates (Fig. 1). Thus, another aspect to be considered is how this $\mathrm{H}_{2} \mathrm{O}_{2}$ would affect the enzyme stability or the reaction itself.

To study if the $\mathrm{H}_{2} \mathrm{O}_{2}$ accumulated during the reaction had some negative effect in enzyme stability, HMFO WT and its variants were incubated for $72 \mathrm{~h}$ with $0-30 \mathrm{mM}$ $\mathrm{H}_{2} \mathrm{O}_{2}$ in Tris/ $\mathrm{HCl}, \mathrm{pH} 7.5$, at $25{ }^{\circ} \mathrm{C}$, and their residual activities were measured with vanillyl alcohol (Fig. 2b). All the enzymes were affected by $\mathrm{H}_{2} \mathrm{O}_{2}$ with the W466F and V367R/W466F variants retaining $<20 \%$ of the initial activity at all the $\mathrm{H}_{2} \mathrm{O}_{2}$ concentrations assayed. In contrast, the $8 \mathrm{BxHMFO}$ multiple variant kept at least $~ 50 \%$ of its activity in the whole $\mathrm{H}_{2} \mathrm{O}_{2}$ range, while the activity of the HMFO WT and V367R variant was always below $50 \%$ at $\mathrm{H}_{2} \mathrm{O}_{2}$ concentrations higher than $3 \mathrm{mM}$.

To discard an additional inhibitory effect of $\mathrm{H}_{2} \mathrm{O}_{2}$ on the FFCA oxidation reaction, as reported for AAO [25], FDCA production from FFCA by HMFO WT was evaluated along $48 \mathrm{~h}$ in the presence of $1.5-18 \mathrm{mM} \mathrm{H}_{2} \mathrm{O}_{2}$ (Additional file 1: Fig. S1). However, no strong differences were observed compared with the FDCA produced 
Table 1 Half-lives (h) of HMFO WT and variants $(2.5 \mu \mathrm{M})$ during FDCA production from HMF and FFCA (1.5 mM) in 48-h reactions, at different $\mathrm{pH}$ values

\begin{tabular}{|c|c|c|c|c|c|}
\hline Enzyme & Substrate & $\mathrm{pH} 6.5$ & $\mathrm{pH} 7.5$ & $\mathrm{pH} 8.0$ & $\mathrm{pH} 9.0$ \\
\hline WT & $\mathrm{OH}$ & 85.6 & 52.5 & 23.0 & 28.5 \\
\hline V367R & & 7.0 & 24.8 & 27.8 & 6.8 \\
\hline W466F & & 3.9 & 8.5 & 8.7 & 3.9 \\
\hline V367R/W466F & HMF & 5.7 & 13.0 & 18.8 & 13.7 \\
\hline 8BxHMFO & FIVIF & 34.1 & 36.1 & 144.0 & 24.4 \\
\hline WT & $\mathrm{HO}$ & 204.0 & 187.0 & 114.0 & 112.0 \\
\hline V367R & & 60.3 & 61.9 & 97.6 & 105.0 \\
\hline W466F & & 18.4 & 26.5 & 40.5 & 38.7 \\
\hline V367R/W466F & & 34.1 & 41.5 & 68.6 & 16.9 \\
\hline $8 \mathrm{~B} \times \mathrm{HMFO}$ & FFCA & 142.0 & 204.0 & 347.0 & 204.0 \\
\hline
\end{tabular}

Residual activities were measured with vanillyl alcohol in $50 \mathrm{mM} \mathrm{Tris/HCl,} \mathrm{pH}$ 7.5. The highest value for each enzyme is shown in bold

in absence of external $\mathrm{H}_{2} \mathrm{O}_{2}$. The $\mathrm{H}_{2} \mathrm{O}_{2}$ generated during catalysis was removed by the addition of catalase to increase the stability of the enzymes. The effect of catalase was milder at low substrate concentrations $(\sim 1.5 \mathrm{mM})$ but it was more relevant at higher HMF concentrations, as described below.

The $\mathrm{H}_{2} \mathrm{O}_{2}$ produced by HMFO along the reaction with

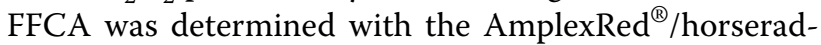
ish peroxidase (HRP) coupled assay, and compared with the amount of FDCA quantified by HPLC (Fig. 3). The results showed stoichiometric amounts of FDCA and $\mathrm{H}_{2} \mathrm{O}_{2}$ along the reaction, indicating that the oxidation of FFCA by HMFO takes place with $\mathrm{H}_{2} \mathrm{O}_{2}$ release. This contrast with the slower catalysis by $\mathrm{AAO}$ that, given the lack of $\mathrm{H}_{2} \mathrm{O}_{2}$ formation, was proposed to occur through a monooxygenase-type mechanism [25]. The difference makes the oxidation of FFCA by HMFO more efficient than by $\mathrm{AAO}$, which requires much longer reaction times.

\section{Effect of FFCA intermediate on FDCA production}

Although HMFO is capable to carry out HMF oxidation to FDCA, its lower activity towards FFCA limits the efficiency of the whole reaction [23, 24]. To displace the reaction towards product formation we evaluated the effect that increasing amounts of HMF or FFCA had on FDCA production by HMFO WT (Fig. 4a and b, respectively). At the highest substrate concentrations assayed $(15 \mathrm{mM})$ the FDCA yields from HMF decreased drastically. The fact that similar inhibition was observed with increasing amounts of FFCA suggests that the reaction is inhibited by this reaction intermediate. In the presence of catalase, the same inhibition profiles were observed upon increasing substrate concentration, although higher FDCA yields were attained, being the highest with 6 mM HMF (Fig. 4a).

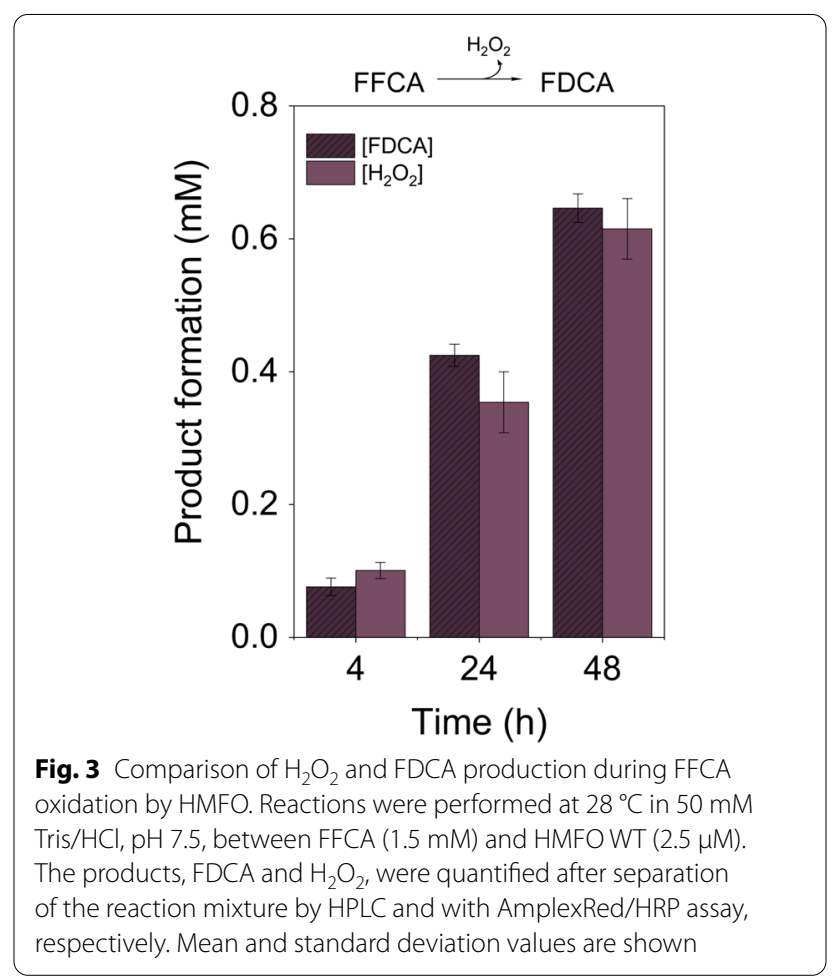

The steady-state kinetics for HMF and DFF oxidations were measured with AmplexRed ${ }^{\circledR} / \mathrm{HRP}$ in a continuous assay. The saturation profiles for all the variants 


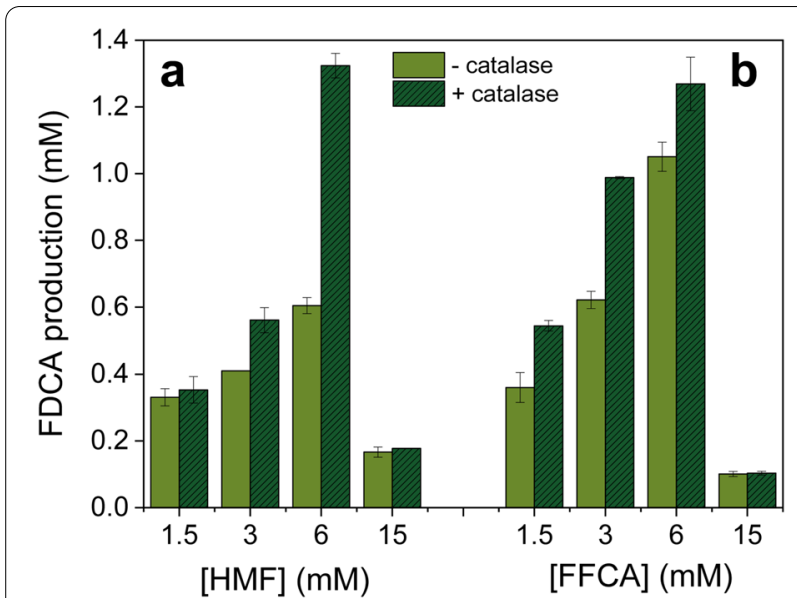

Fig. 4 FDCA production from different HMF (a) and FFCA (b) concentrations and catalase effect. FDCA production by HMFO WT $(2.5 \mu \mathrm{M})$ from increasing HMF (left) and FFCA (right) concentrations $(1.5-15 \mathrm{mM})$ is shown in the absence and presence of catalase. Reactions (48 h) were performed in $50 \mathrm{mM}$ Tris/ $\mathrm{HCl}, \mathrm{pH} 7.5$, at $28^{\circ} \mathrm{C}$. Mean and standard deviation values are shown discarded any inhibitory effect by these two substrates (Additional file 1: Fig. S2 and Table S1). However, an end-point method was required to analyze the kinetics for FFCA oxidation, given the much lower activities on this substrate. Since important differences in FDCA yields from FFCA were observed depending on $\mathrm{pH}$, these kinetic measurements were performed at $\mathrm{pH}$ values from 6.0 to 9.0, and an excess of catalase was added to ensure the enzyme stability. Reactions were stopped after $48 \mathrm{~h}$ for HMFO WT and after 30 min for the improved HMFO variants, and the FDCA formed was quantified by HPLC (Fig. 5). Both HMFO WT and variants showed a strong inhibition by FFCA that, surprisingly, was highly dependent on $\mathrm{pH}$. To better understand this inhibition, residual activity of HMFO WT was measured (with vanillyl alcohol) when FFCA was added (time $0 \mathrm{~h}$ ) and before stopping the reaction after $48 \mathrm{~h}$, at the different substrate concentrations used in the kinetic curves (Additional file 1: Fig. S3a and b). The results indicate that at those FFCA concentrations where inhibition was detected, the enzymatic activity was lost from the moment that enzyme and FFCA were put together. To know if this inhibition could be reverted, enzymes were dialyzed in
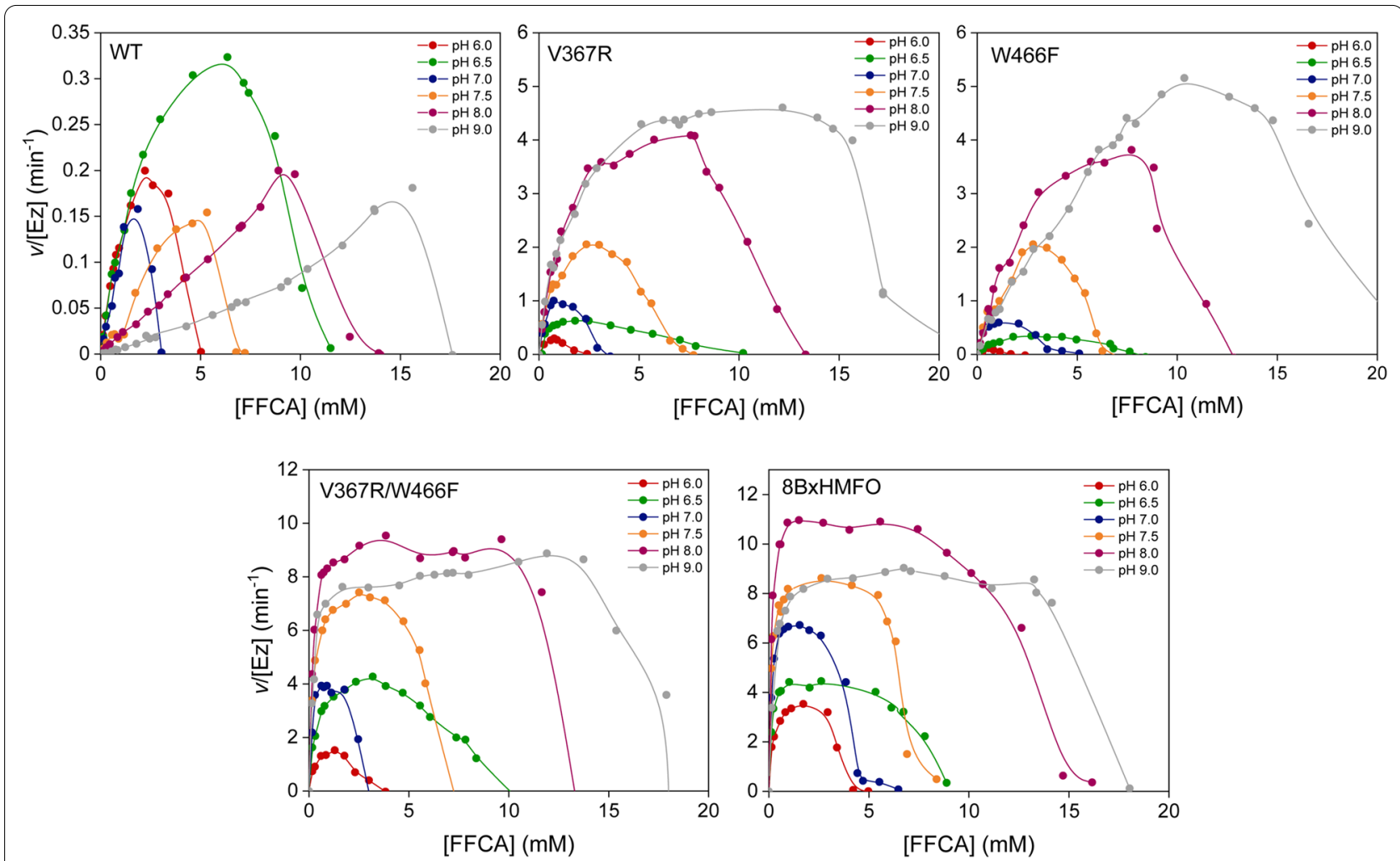

Fig. 5 Effect of $\mathrm{pH}$ on kinetic curves of FFCA oxidation by HMFO WT and variants. Reaction rates $(v /[\mathrm{Ez}]$ as $\mu \mathrm{mol}$ of product per $\mu \mathrm{mol}$ of enzyme per time, in $\mathrm{min}^{-1}$ ) were obtained for end-point reactions of HMFO WT, and its V367R, W466F, V367R/W466F and 8BxHMFO variants with increasing amounts of FFCA, in $50 \mathrm{mM} \mathrm{NaPi}\left(\mathrm{pH}\right.$ 6.0-6.5) or Tris/ $\mathrm{HCl}(\mathrm{pH} 7.0-9.0)$ at $25^{\circ} \mathrm{C}$, in the presence of catalase. FDCA production was quantified in 48-h and 30-min reactions for the HMFO WT and variants, respectively 
$50 \mathrm{mM}$ Tris $/ \mathrm{HCl}$ overnight, $\mathrm{pH} 7.5$, after their incubation with $15 \mathrm{mM}$ FFCA for $5 \mathrm{~min}$. However, all of them remained inactive (data not shown) indicating irreversible inhibition by FFCA. These data suggest that FFCA would bind at the active site or in its access channel preventing the enzyme to act in successive catalytic cycles.

Due to the high inhibition observed at different $\mathrm{pH}$ values (Fig. 5), only apparent kinetic constants for FFCA could be calculated for each enzyme and $\mathrm{pH}$ (Table 2). Catalytic efficiencies were the highest at $\mathrm{pH} 6.0$ for

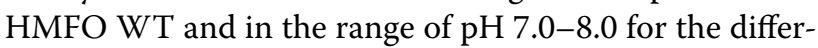
ent variants. For all the enzymes, inhibition occurred at higher substrate concentrations when kinetics were performed at more basic $\mathrm{pH}$. Moreover, 8BxHMFO showed better catalytic efficiencies than V367R/W466F and the other variants at any $\mathrm{pH}$ tested. This $\mathrm{pH}$-dependent inhibition by FFCA is in agreement with the efficiencies observed at the different $\mathrm{pH}$ values in long-term HMF and FFCA reactions (Fig. $2 \mathrm{c}$ and d), being the optimal $\mathrm{pH}$ for these conversions those in which the enzymes present less FFCA inhibition (within the $\mathrm{pH}$ range in which the highest apparent efficiencies are observed).

\section{Effect of $\mathrm{O}_{2}$ concentration on FDCA production}

The high enzyme inhibition by FFCA prevented evaluation of the reaction under saturating HMF concentrations. However, we were able to evaluate the effect of oxygen saturation (the second substrate required by the oxidase) on FDCA production by HMFO WT and its variants. With this purpose, the enzymes were mixed with $6 \mathrm{mM}$ HMF and catalase excess at $28{ }^{\circ} \mathrm{C}$, bubbled with $\mathrm{O}_{2}$, corresponding to $1.22 \mathrm{mM}$ concentration [33], and the FDCA yields were compared with those obtained using atmospheric $\mathrm{O}_{2}$, corresponding to $0.25 \mathrm{mM}$ concentration, after 48-h reaction (Additional file 1: Fig S4a). Although in the case of HMFO WT some improvement was observed at higher $\mathrm{O}_{2}$ concentration, for the HMFO variants, which are more efficient for FFCA oxidation,

Table 2 Apparent catalytic efficiencies $\left(k_{\text {cat }} / K_{\mathrm{m}}, \mathrm{mM}^{-1} \mathrm{~min}^{-1}\right)$ for FFCA oxidation by HMFO WT and variants, at different $\mathrm{pH}$ values

\begin{tabular}{lllllc}
\hline $\mathbf{p H}$ & $\mathbf{W T}^{\mathbf{a}}$ & V367R & $\mathbf{W 4 6 6 F}^{\mathbf{a}}$ & $\begin{array}{l}\text { V367R/ } \\
\text { W466F }\end{array}$ & $\mathbf{8 B x H M F O}$ \\
\hline 6.0 & $0.24 \pm 0.04$ & $1.6 \pm 0.6$ & $0.21 \pm 0.01$ & $8.2 \pm 2.2$ & $24.9 \pm 4.3$ \\
6.5 & $0.18 \pm 0.01$ & $3.0 \pm 0.2$ & $0.55 \pm 0.10$ & $13.6 \pm 1.4$ & $51.6 \pm 11.1$ \\
7.0 & $0.10 \pm 0.01$ & $4.9 \pm 1.7$ & $1.84 \pm 0.32$ & $42.3 \pm 14.4$ & $76.8 \pm 11.2$ \\
7.5 & $0.033 \pm 0.001$ & $4.1 \pm 0.7$ & $1.65 \pm 0.24$ & $43.2 \pm 2.6$ & $95.9 \pm 12.2$ \\
8.0 & $0.023 \pm 0.001$ & $3.7 \pm 0.3$ & $1.84 \pm 0.32$ & $66.4 \pm 7.3$ & $130.0 \pm 16.0$ \\
9.0 & $0.009 \pm 0.001$ & $3.2 \pm 0.3$ & $1.65 \pm 0.24$ & $44.8 \pm 5.2$ & $45.1 \pm 2.9$ \\
\hline
\end{tabular}

${ }^{a}$ For HMFO WT in $\mathrm{pH} \geq 7$ and for $\mathrm{W} 466 \mathrm{~F}$ in all the $\mathrm{pH}$ range, the efficiencies were estimated as $k_{\mathrm{obs}} /[\mathrm{FFCA}]$ ratios due to the lack of enzyme saturation (before its inhibition). Mean and standard deviation values are shown similar results were obtained under both conditions. This suggests that the current reactions would be already saturated under atmospheric $\mathrm{O}_{2}$. Nevertheless, additional improvements enabling use of higher substrate concentrations, an important point for scaling up the process, could be obtained by increasing the $\mathrm{O}_{2}$ diffusion into the reaction medium. In this sense, continuous-flow microreactor technology has been reported as a safe and scalable way to approach oxidation reactions $[34,35]$ and different reactor designs - such as simple flow reactors, tubein-tube reactors, agitated tube reactors and continuous agitated cell reactors-have been used for $\mathrm{O}_{2}$-dependent enzymes showing higher oxygen transfer rates than in batch reactions [36-40].

\section{Effect of FAD addition on FDCA production}

It has been suggested that higher FDCA yields can be attained by adding FAD to HMFO WT reactions [23] to prevent eventual inactivation of the enzyme by cofactor dissociation. Although such effect was claimed based on 95\% FDCA yield in 24-h reactions of $4 \mathrm{mM}$ HMF (and $20 \mu \mathrm{M}$ HMFO) in presence of $20 \mu \mathrm{M}$ FAD, the study lacked the FAD-less controls (with $4 \mathrm{mM}$ HMF and $20 \mu \mathrm{M}$ HMFO) to demonstrate such effect. Therefore, to confirm/discard a positive effect of FAD, HMF $(6 \mathrm{mM})$ reactions with and without $20 \mu \mathrm{M}$ FAD, in $\mathrm{pH}$ $6.550 \mathrm{mM} \mathrm{NaPi}$ for HMFO WT and $\mathrm{pH} 8.0$ Tris/HCl for the variants, were performed here. The FDCA yields and residual activities of the enzymes (enabling half-life, $t_{1 / 2}$, calculation) were followed along $48 \mathrm{~h}$ (Table 3 and Additional file 1: Fig. S4b). No differences were observed for HMFO WT and V367R, while a slight increase was observed when FAD was added to variants bearing the W166F mutation ( 1.1-fold for 8BxHMFO and 1.5 fold for W466F and V367R/W466F). Since the efficiency for FFCA oxidation was similar in absence and presence of FAD (Additional file 1: Table S2) the slight effect of the cofactor can be attributed to higher stability of these variants when FAD was added to the reaction (with halflives 1.2-1.5-folds higher than in absence of the cofactor). These results make sense for variants containing a mutation at W466, since this residue is close to the flavin ring, and its removal affect protein stability [31].

Anyway, it is necessary to remark that the effect of FAD is much lower than the effect of adding catalase to the reaction (Table 3 and Additional file 1: Fig. S4b). The removal of $\mathrm{H}_{2} \mathrm{O}_{2}$ by catalase positively affects both stabilities and FDCA yields for all the enzymes. An improvement of 1.5-3-folds was observed for most of the variants and up to 9-folds for W466F, while the half-lives significantly increased for HMFO WT and the V367R and 8 BxHMFO variants. In these conditions, variants V367R and 8BxHMFO achieved full conversion of 
Table 3 Effect of FAD or/and catalase on catalytic performance parameters-FDCA concentration (mM) and yield (\%), enzyme halflife $\left(t_{1 / 2}\right)$, and total turnover number (TTN)_for the production of FDCA from HMF (6 mM) by the HMFO WT and variants

\begin{tabular}{|c|c|c|c|c|c|c|}
\hline Enzyme & FAD & Catalase & FDCA (mM) & FDCA (\%) & $t_{1 / 2}(h)$ & $\overline{\text { TTN }}$ \\
\hline \multirow[t]{4}{*}{ WT } & - & - & 1.4 & 23 & 16 & 1650 \\
\hline & + & - & 1.4 & 23 & 17 & 1680 \\
\hline & - & + & 2.1 & 35 & 178 & 2520 \\
\hline & + & + & 3.1 & 53 & 210 & 3810 \\
\hline \multirow[t]{4}{*}{ V367R } & - & - & 3.5 & 58 & 19 & 4200 \\
\hline & + & - & - & 59 & 18 & 4240 \\
\hline & - & + & 6.0 & 100 & 128 & 7200 \\
\hline & + & + & 6.0 & 100 & 315 & 7200 \\
\hline \multirow[t]{4}{*}{ W466F } & - & - & - & 8 & 23 & 605 \\
\hline & + & - & - & 12 & 27 & 880 \\
\hline & - & - & 4.8 & 80 & 35 & 5730 \\
\hline & + & + & 4.0 & 67 & 49 & 4820 \\
\hline \multirow[t]{4}{*}{ V367R/W466F } & - & - & - & 24 & 24 & 1740 \\
\hline & + & - & - & 37 & 34 & 2650 \\
\hline & - & - & 4.3 & 74 & 64 & 5350 \\
\hline & + & + & 3.2 & 53 & 76 & 3800 \\
\hline \multirow[t]{4}{*}{ 8BxHMFO } & - & - & - & 87 & 26 & 6240 \\
\hline & + & - & - & 96 & 38 & 6900 \\
\hline & - & - & 6.0 & 100 & 204 & 7200 \\
\hline & + & + & 6.0 & 100 & 315 & 7200 \\
\hline
\end{tabular}

Reactions were performed using $6 \mathrm{mM} \mathrm{HMF}$ and $2.5 \mu \mathrm{M}$ enzyme in $50 \mathrm{mM} \mathrm{NaPi}, \mathrm{pH} 6.5$ (for HMFO WT) and $50 \mathrm{mM} \mathrm{Tris/} \mathrm{HCl}$, pH 8.0 (for the $\mathrm{HMFO}$ variants), at $28{ }^{\circ} \mathrm{C}$. $20 \mu \mathrm{M}$ FAD and/or catalase excess were added, when indicated

$6 \mathrm{mM}$ HMF into FDCA after $48 \mathrm{~h}$ of reaction. Moreover, although the addition of catalase plus FAD increased the half-life of all the enzymes, the FDCA yield was only increased for HMFO WT (while FDCA production by its variants was similar to that observed upon the only addition of catalase). Finally, it was confirmed that only traces of HMFCA $(<1 \%)$ were produced in HMF controls with and without catalase or FAD in the absence of enzyme, excluding any activity of catalase or FAD oxidizing these furfurals (Additional file 1: Fig. S5).

\section{Optimized conditions for FDCA production}

Taking all the above results together, the conditions for FDCA production with the HMFO enzymes were optimized. Among the variants analyzed, V367R and 8BxHMFO were selected as the most suitable for the scalability of the process, since they exhibit higher stability and better performance. Reactions were carried out at $\mathrm{pH} 8.0$ (in $50 \mathrm{mM}$ Tris/ $\mathrm{HCl}$ ) since this is the optimal pH for FDCA production by these variants (Fig. 2). The stability of the enzymes during the reactions was ensured by addition of a catalase excess, as shown by their higher half-life under these conditions (Table 3). The addition of FAD was excluded since the benefit is not relevant, as shown above, and the high cost of the cofactor limits its use for an industrial application.

Considering the relatively low substrate concentration used in the previous experiments, we explored increasing HMF concentrations (up to $12 \mathrm{mM}$, since accumulation of higher concentrations of FFCA results in enzyme inhibition, Fig. 5). However, the final amounts of FDCA product were barely improved, reaching $<7.5 \mathrm{mM}$ of FDCA after 6 days of reaction, despite of the use of higher HMF concentration (Additional file 1: Fig. S6a). Moreover, under these conditions, the stability of the enzymes decreased drastically over time (Table 4 and Additional file 1: Fig. S6b).

Therefore, taking advantage of the high residual activity of V367R and 8BxHMFO at the end of reactions with $6 \mathrm{mM}$ HMF, we decided to supplement the reactions with additional $6 \mathrm{mM}$ HMF and catalase excess when the first conversion was completed after 2 days (Fig. 6a). In this way, almost $10 \mathrm{mM}$ FDCA was attained in 6 days reaching total turnover numbers (TTN) over 11,000 (Table 4). As FFCA accumulation under these conditions could result in enzyme inactivation limiting final product concentration, lower enzyme doses $(1.25 \mu \mathrm{M})$ were assayed 
Table 4 Catalytic performance parameters-FDCA concentration (mM) and yield (\%), residual activity, and total turnover number (TTN) — for the production of FDCA from 6-12 mM HMF (including $6 \mathrm{mM}$ re-dosage after $6 \mathrm{mM}$ initial concentration) by the V367R and $8 \mathrm{BxHMFO}$ variants

\begin{tabular}{|c|c|c|c|c|c|c|}
\hline Enzyme & HMF (mM) & Enzyme $(\mu \mathrm{M})$ & FDCA (mM) & FDCA (\%) & $\begin{array}{l}\text { Residual activity } \\
\text { (\%) }\end{array}$ & TTN \\
\hline \multirow[t]{6}{*}{ V367R } & 6 & 2.50 & 6.0 & 100 & 67 & 7200 \\
\hline & 8 & 2.50 & 7.0 & 88 & 0 & 8460 \\
\hline & 10 & 2.50 & 5.0 & 50 & 0 & 6025 \\
\hline & 12 & 2.50 & 2.0 & 17 & 0 & 2376 \\
\hline & $6+6^{a}$ & 2.50 & 9.3 & 78 & 2 & 11,200 \\
\hline & $6+6^{b}$ & 1.25 & 11.7 & 98 & 3 & 27,400 \\
\hline \multirow[t]{6}{*}{ 8BxHMFO } & 6 & 2.50 & 6.0 & 100 & 75 & 7200 \\
\hline & 8 & 2.50 & 7.4 & 92 & 10 & 8830 \\
\hline & 10 & 2.50 & 6.1 & 60 & 8 & 7204 \\
\hline & 12 & 2.50 & 5.3 & 45 & 4 & 6500 \\
\hline & $6+6^{a}$ & 2.50 & 9.6 & 80 & 37 & 11,600 \\
\hline & $6+6^{b}$ & 1.25 & 10.7 & 89 & 36 & 26,200 \\
\hline
\end{tabular}

Reactions were performed in $50 \mathrm{mM}$ Tris/ $\mathrm{HCl}, \mathrm{pH} 8.0$, for 6 days ( 12 days when the enzyme concentration was reduced to $1.25 \mu \mathrm{M}$ ) in the presence of catalase excess. The residual HMFO activity was estimated with vanillyl alcohol, and presented as percentage of the initial activity

a,b Substrate $(6 \mathrm{mM})$ plus catalase re-dosage was done after 2 and 4 days of reaction, respectively
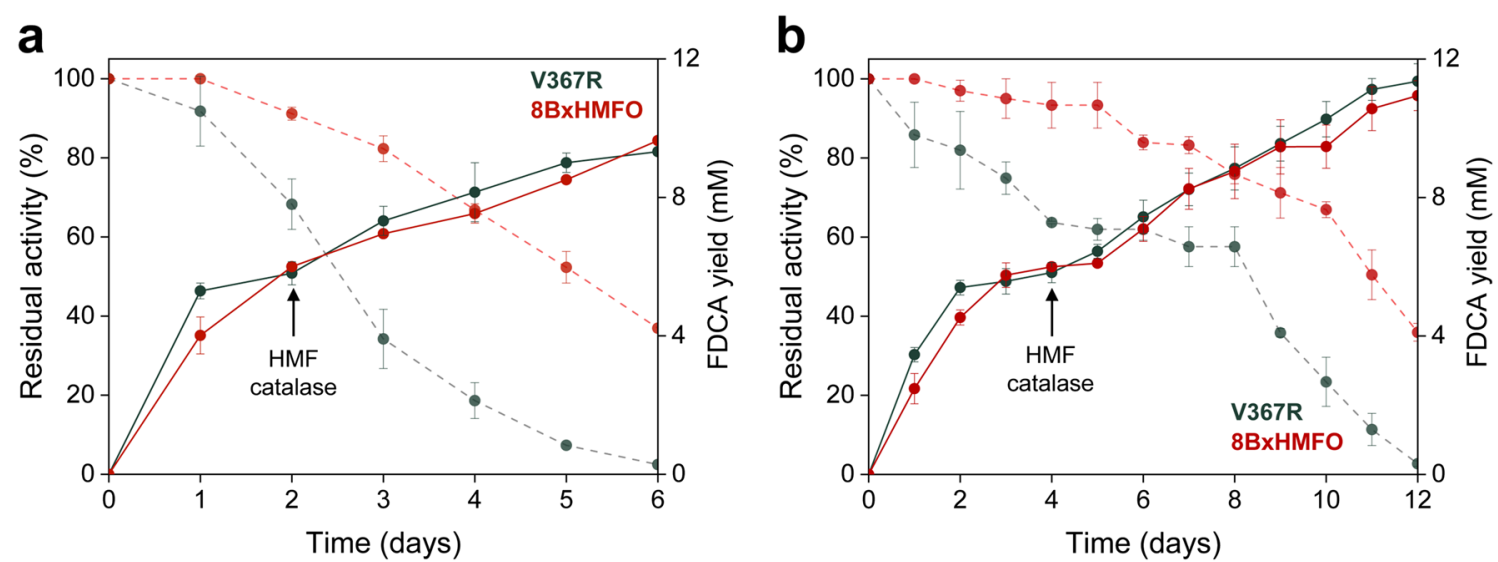

Fig. 6 Optimized HMF conversion using two different V367R and 8BxHMFO doses. a Reactions with $2.5 \mu \mathrm{M}$ enzyme, and HMF/catalase re-dosage after 2 days. $\mathbf{b}$ Higher FDCA production by lowering the enzyme dose (to $1.25 \mu \mathrm{M}$ ), and HMF/catalase re-dosage after 4 days. FDCA yields (lines) and residual enzyme activities (dashes) are shown during HMF (6 mM concentration, plus $6 \mathrm{mM}$ addition after 2 or 4 days) reactions with the V367R (black) and 8BxHMFO (red) variants, in $50 \mathrm{mM}$ Tris/ $\mathrm{HCl}, \mathrm{pH}$ 8.0, in the presence of catalase. FDCA production was quantified by HPLC, and residual activities were measured with vanillyl alcohol, in $50 \mathrm{mM}$ Tris/HCl, $\mathrm{pH}$ 7.5. Mean and standard deviation values from triplicate experiments are shown

(Fig. 6b). Under these conditions, slower production and minor accumulation of FFCA was expected, resulting in more active enzyme being able to complete the conversion till FDCA. With this amount of enzyme, a second addition of substrate and catalase was applied after 4 days of reaction, when no more conversion was observed. In this way, almost $12 \mathrm{mM}$ FDCA was obtained after 12 days, before enzyme inactivation, and TTN values of 26,000 and 27,000 were reached for the $8 \mathrm{BxHMFO}$ and V367R variants, respectively (Table 4). Therefore, taking advantage from the high stability of both variants under optimized conditions, we were able to double the FDCA yields obtained by re-dosing substrate to overcome the inhibition by the intermediate FFCA. By applying these reaction conditions, FDCA yields $\geq 90 \%$ are attained facilitating downstream procedures to obtain pure FDCA. However, further reaction upscaling is necessary for more realistic evaluation of product purification under industrially-relevant conditions. 


\section{Conclusions}

Biocatalysts for industrial processes must fulfill specific features to ensure the feasibility and applicability of the resulting bioprocess. Aspects such as enzyme stability, cofactor requirement, reaction conditions and substrate range have to be optimized for industrial application [41]. Here, we have identified several limitations of HMFO that can prevent an efficient production of FDCA from HMF, such as the low stability of the enzyme under high concentrations of $\mathrm{H}_{2} \mathrm{O}_{2}$, and its strong inhibition by the FFCA intermediate. However, the above limitations in the enzymatic production of FDCA from HMF can be overcome with the addition of catalase to the reaction mixture and controlling the dose of substrate, respectively. Other aspects such as $\mathrm{O}_{2}$ diffusion into the reaction medium are also important for a further optimization of these processes. The above findings should be taken into account for the use of HMFO variants in an industrial context. They will also pave the way for the characterization of other HMFOs as well as in the development of new variants that enable a more efficient production of FDCA from HMF.

\section{Materials and methods Chemicals}

HMF was kindly provided by AVA Biochem. DFF, FDCA, FAD, catalase, HRP, vanillyl alcohol was purchased from Sigma-Aldrich (St. Louis, MO, USA). FFCA was purchased from TCI America (Portland, OR, USA). AmplexRed $^{\circledR}$ was obtained from Invitrogen (Walthem, MA, USA).

\section{Genes, plasmid and site-directed mutagenesis}

The gene encoding HMFO from Methylovorus sp MP688 (NCBI accession number WP_013440946) was synthesized by ATG biosynthetic (Merzhausen, Germany) and then subcloned into the pET23b $(+)$ plasmid (Novagen). Simple variants of HMFO were performed by whole plasmid PCR using the pET23b-HMFO plasmid as a template. Forward and reverse primers were designed complementary to opposite strands of the DNA region containing the desired mutation. The sequence of the forward synthetic primers (substituted nucleotides are in bold and the triplet containing the mutation is underlined) were 5'-GCA AGC GCT CGT TTC TGG GTG AAC AAG C-3' for V367R and 5'-C GTC GGC GGT GTT TTT CAT GCG AG-3' for W466F. For V367R/ W466F, W466F primers were employed using variant V367R as template. Template DNA was cleaved with DpnI (Roche). E. coli DH5 $\alpha$ cells were transformed with the plasmids through thermal shock. Plasmid purification from $E$. coli DH5 $\alpha$ cultures in LB-ampicillin $100 \mu \mathrm{g} /$ $\mathrm{mL}$ was carried out using High Pure Plasmid Isolation Kit
(Roche). The octuple HMFO variant (8BxHMFO) containing mutations I73V, H74Y, G356K, V367R, T414K, A419Y, A435E and W466F was synthesized by ATG biosynthetic (Merzhausen, Germany) and subcloned into the pET23b $(+)$ plasmid (Novagen). Introduction of mutations was confirmed by sequencing.

\section{Enzyme production and purification of HMFOs}

For recombinant protein expression, the constructed plasmids were transformed into E. coli BL21(DE3)pLysS cells. Overnight cultured cells were diluted 1:30 in $1 \mathrm{~L}$ of LB medium containing $100 \mu \mathrm{g} / \mathrm{mL}$ ampicillin and $34 \mu \mathrm{g} /$ $\mathrm{mL}$ chloramphenicol, and grown at $37{ }^{\circ} \mathrm{C}$ and $200 \mathrm{rpm}$ until an $\mathrm{OD}_{500 \mathrm{~nm}}$ of 1.0 was reached. Cells were induced with $0.1 \mathrm{mM}$ isopropyl $\beta$-D-1-thiogalactopyranoside for $72 \mathrm{~h}$ at $16{ }^{\circ} \mathrm{C}$ and $150 \mathrm{rpm}$. Cells were harvested by centrifugation at $7000 \mathrm{rpm}$ for $5 \mathrm{~min}$ at $4{ }^{\circ} \mathrm{C}$ and frozen for the expression of lysozyme. Bacterial pellets were resuspended in lysis buffer $(50 \mathrm{mM}$ Tris $/ \mathrm{HCl}, \mathrm{pH} 8.0$, supplemented with $10 \mathrm{mM}$ EDTA and $5 \mathrm{mM}$ dithiothreitol) and treated with $0.1 \mathrm{mg} / \mathrm{mL}$ of DNase (Roche) at $4{ }^{\circ} \mathrm{C}$ for $30 \mathrm{~min}$. The cell extracts were obtained after cell disruption through sonication (10 cycles of $1 \mathrm{~min}$ at $4{ }^{\circ} \mathrm{C}$ ), centrifugation at $13,000 \mathrm{rpm}$ and $4{ }^{\circ} \mathrm{C}$ for $30 \mathrm{~min}$, and ultracentrifugation of supernatant at $30,000 \mathrm{rpm}$ and $4{ }^{\circ} \mathrm{C}$ for $1 \mathrm{~h}$ to eliminate insoluble debris. The soluble fraction obtained was preserved at $-20{ }^{\circ} \mathrm{C}$ until its purification.

Native HMFO and variants were purified following the same protocol previously described for HMFO WT [24]. Two consecutive anionic-exchange chromatographic steps, first with a Resource Q 6-mL (GE Healthcare) column and then with Mono Q 5/50 GL 1-mL column were used to obtain pure fractions of the enzymes. The purification process was followed by analyzing each fraction in a SDS-PAGE $12 \%(v / v)$ polyacrylamide separation gel (Additional file 1: Fig. S7).

\section{Spectral properties of HMFOs}

The UV-visible spectra of the purified proteins were recorded between 250 and $700 \mathrm{~nm}$ in a Cary4000 spectrophotometer. The spectra of the folded enzymes and the free flavin, obtained by heat treatment of the enzyme (95 ${ }^{\circ} \mathrm{C}$ for $5 \mathrm{~min}$ ) and centrifugation for $45 \mathrm{~min}$, were recorded to calculate the extinction coefficient at the bandI of the flavin, using the known extinction constant for FAD $\left(\varepsilon_{450 \mathrm{~nm}}=11,300 \mathrm{mM}^{-1} \mathrm{~cm}^{-1}\right)$ [42] (Additional file 1: Table S3). The calculated extinction coefficient of each variant was used to estimate the protein concentrations.

\section{$\mathrm{pH}$ and $\mathrm{H}_{2} \mathrm{O}_{2}$ stability of native $\mathrm{HMFO}$ and variants} $\mathrm{pH}$ stability was estimated by incubating the purified enzymes at different $\mathrm{pH}$ (6-9) in Britton-Robinson buffer. 
To determine stability to $\mathrm{H}_{2} \mathrm{O}_{2}$, purified enzymes were incubated in the presence of 0 to $30 \mathrm{mM} \mathrm{H}_{2} \mathrm{O}_{2}$ in $50 \mathrm{mM}$ Tris/ $\mathrm{HCl}, \mathrm{pH}$ 7.5. Samples were incubated at $25{ }^{\circ} \mathrm{C}$ and residual activities were measured at $0,24,48$ and $72 \mathrm{~h}$ by oxidation of $3 \mathrm{mM}$ vanillyl alcohol in $50 \mathrm{mM}$ Tris/ $\mathrm{HCl}, \mathrm{pH}$ 7.5 , at $25^{\circ} \mathrm{C}$. For each enzyme, the highest activity obtained at the different times and $\mathrm{pH}$ or $\mathrm{H}_{2} \mathrm{O}_{2}$ conditions was taken as $100 \%$, and the percentages of residual activity of the remaining measures were referred to this value.

\section{FDCA production by HMFOs}

Effect of $\mathrm{pH}$ on HMF and FFCA oxidation was determined by analyzing FDCA yields after incubating each enzyme $(2.5 \mu \mathrm{M})$ with HMF or FFCA $(1.5 \mathrm{mM})$ in $50 \mathrm{mM} \mathrm{NaPi}$, $\mathrm{pH}$ 6.5, and in $50 \mathrm{mM}$ Tris/ $\mathrm{HCl}, \mathrm{pH} 7.5,8.0$ and 9.0. Effect of $\mathrm{H}_{2} \mathrm{O}_{2}$ on FDCA production was analyzed by incubating HMFO WT $(2.5 \mu \mathrm{M})$ with HMF $(1.5 \mathrm{mM})$ in presence of different concentrations of $\mathrm{H}_{2} \mathrm{O}_{2}$. FDCA: $\mathrm{H}_{2} \mathrm{O}_{2}$ stoichiometry was evaluated by quantifying FDCA by HPLC (see below) and $\mathrm{H}_{2} \mathrm{O}_{2}$ using AmplexRed ${ }^{\circledR} / \mathrm{HRP}$. Effect of oxygen was studied by analyzing FDCA yields after incubation of the enzymes $(2.5 \mu \mathrm{M})$ with HMF $(6 \mathrm{mM})$ and catalase excess $(10-25 \mathrm{U} / \mathrm{mL})$ and bubbling the reactions with $1.22 \mathrm{mM}$ of $\mathrm{O}_{2}$. Effect of cofactor addition was assayed by incubating the enzymes $(2.5 \mu \mathrm{M})$ with $6 \mathrm{mM}$ HMF $(6 \mathrm{mM})$ with and without the addition of FAD $(20 \mu \mathrm{M})$.

All reactions (unless indicated) were performed in $50 \mathrm{mM} \mathrm{NaPi}, \mathrm{pH}$ 6.5, for HMFO WT and $50 \mathrm{mM}$ Tris/HCl, $\mathrm{pH}$ 8.0, for HMFO variants, at $28{ }^{\circ} \mathrm{C}$ under continuous shaking $(180 \mathrm{rpm})$. In all cases, solutions were treated in the same conditions but in the absence of enzyme as negative controls.

Residual activity of HMFOs along the reactions was measured just after taking aliquots at different times (usually $0,4,24$ and $48 \mathrm{~h}$ or every $24 \mathrm{~h}$ in longer reactions), before addition of $\mathrm{HCl}$, by monitoring their activity against vanillyl alcohol. The activity decay as a function of time was calculated from Eq. 1 allowing the estimation of the halflife (Eq. 2):

$$
\begin{aligned}
& \text { HMFOactivity }(\%)=\text { HMFOact }_{0} \cdot e^{-\lambda t} \\
& t_{1 / 2}=\frac{\ln (2)}{\lambda}
\end{aligned}
$$

where $\lambda$ is the activity decay constant, and $t_{1 / 2}$ is the enzyme half-life.

\section{Product identification}

After substrate conversion, $150 \mu \mathrm{L}$ aliquots were taken at different times (usually $0,4,24$ and $48 \mathrm{~h}$ or every $24 \mathrm{~h}$ in longer reactions) and reactions were stopped by adding $1 \mathrm{M} \mathrm{HCl}$ up to $\mathrm{pH} 2-3$. Furfural oxidation was analyzed by HPLC using an ion-exchange SUPELCOGEL C-610H column $(300 \times 7.8 \mathrm{~mm}, 9 \mu \mathrm{m}$ particle size, SUPELCO $)$. Compounds were eluted using $5 \mathrm{mM} \mathrm{H}_{2} \mathrm{SO}_{4}$ as mobile phase at a flow rate of $0.6 \mathrm{~mL} / \mathrm{min}$ at $30{ }^{\circ} \mathrm{C}$ and detection was done at $264 \mathrm{~nm}$. The retention times of FDCA, HMFCA, FFCA, HMF and DFF were 21, 27, 30, 42 and $52 \mathrm{~min}$, respectively (Additional file 1: Fig. S8). Calibration curves were made with $0.05,0.1,0.2,0.4,0.75$ and $1.5 \mathrm{mM}$ solutions of each component that might be present during the reaction. $\mathrm{H}_{2} \mathrm{O}_{2}$ quantification was performed using a peroxidase coupled assay before the addition of $\mathrm{HCl}$. In this assay, HRP $(6 \mathrm{U} / \mathrm{mL}$ final concentration) reacts with AmplexRed ${ }^{\circledR}$ reagent $(75 \mathrm{ng} / \mathrm{mL}$ final concentration) in presence of $\mathrm{H}_{2} \mathrm{O}_{2}$ producing a pink product (resorufin; $\varepsilon_{563 \mathrm{~nm}}=52,000 \mathrm{M}^{-1} \mathrm{~cm}^{-1}$ ). Quantification was performed using a calibration curve with known concentrations of $\mathrm{H}_{2} \mathrm{O}_{2}$. The standard deviations were always $\leq 5 \%$ of the mean values obtained.

\section{Kinetic analysis}

Steady-state kinetic parameters for HMF and DFF oxidation by HMFOs were calculated by monitoring the production of $\mathrm{H}_{2} \mathrm{O}_{2}$ during oxidation of the different substrates using a HRP-coupled assay with AmplexRed ${ }^{\circledR}$ as final substrate in $50 \mathrm{mM}$ Tris $/ \mathrm{HCl}, \mathrm{pH} 7.0$, as previously described [24]. The oxidation of FFCA was measured in end-time mode by incubating different concentrations of FFCA $(0.4-25 \mathrm{mM})$ with the enzymes $(0.3-1.5 \mu \mathrm{M}$, depending on the enzyme) supplemented with catalase excess $(10-25 \mathrm{U} / \mathrm{mL})$ at $25{ }^{\circ} \mathrm{C}$ in $50 \mathrm{mM} \mathrm{NaPi}, \mathrm{pH}$ 6.0-6.5, or $50 \mathrm{mM}$ Tris/HCl, $\mathrm{pH} 7.0-9.0$, under continuous shaking. Reactions were stopped after $48 \mathrm{~h}$ for WT HMFO or at 30 min for HMFO variants, and the products were quantified by HPLC as described above. The rate of FDCA or $\mathrm{H}_{2} \mathrm{O}_{2}$ formation $(v /[\mathrm{Ez}])$ was estimated as the product formed $(\mu \mathrm{mol})$ per enzyme concentration ( $\mu \mathrm{mol}$ ) per time of reaction (resulting in $\mathrm{min}^{-1}$ units).

In all cases, kinetic parameters were determined by fitting the initial reaction rates at different alcohol or aldehyde concentrations to the Michaelis-Menten equation (Eq. 3) using Origin software.

$$
\frac{\nu_{0}}{[E]}=\frac{k_{c a t}[S]}{K_{m}+[S]}
$$

where $k_{\text {cat }}$ is the catalytic constant, and $K_{\mathrm{m}}$ is the Michaelis-Menten constant.

When apparent kinetic parameters could not be estimated, the linear relation between the rates $\left(\mathrm{min}^{-1}\right)$ 
and the substrate concentration $(\mathrm{mM})$ was used as a measure of catalytic efficiency $\left(k_{\mathrm{obs}} /[\mathrm{FFCA}]\right)$.

\section{Abbreviations}

AAO: Aryl-alcohol oxidase; FDCA: 2,5-Furandicarboxylic acid; FFCA: 5-Formylfurancarboxylic acid; GMC: Glucose-methanol-choline oxidase/dehydrogenase (enzyme superfamily); HMF: 5-Hydroxymethylfurfural; HMFCA: 5-Hydroxymethylfurancarboxylic acid; HMFO: HMF oxidase; HPLC: High-performance liquid chromatography; HRP: Horseradish peroxidase; $k_{\text {cat }}$ : Catalytic constant; $k_{\text {cat }} / K_{m}$ : Catalytic efficiency; $K_{m}$ : Michaelis constant; PEF: Poly(ethylene-2,5-furandicarboxylate); PET: Poly(ethylene-terephthalate); TTN: Total turnover number

\section{Supplementary Information}

The online version contains supplementary material available at https://doi. org/10.1186/s12934-021-01669-1.

Additional file 1: Table S1. Steady-state kinetic parameters for HMF, DFF and FFCA oxidation. Table S2. Effect of FAD on FFCA oxidation. Table S3. Spectroscopic properties of the HMFOWT and variants. Fig. S1. Effect of $\mathrm{H}_{2} \mathrm{O}_{2}$ on FDCA production from FFCA. Fig. S2. Kinetic curves of HMF and DFF oxidation. Fig. S3 Effect of FFCA on HMFO kinetics and residual activity. Fig. S4. Effect of oxygen, FAD and catalase on FDCA production. Fig. S5. HMF control reactions without HMFO. Fig. S6. Reactions of HMFO variants with different HMF concentrations. Fig. S7. SDS-PAGE of purified HMFOs. Fig. S8. HPLC separation of HMF-derived furfurals.

\section{Acknowledgements}

We acknowledge support of the publication fee by the CSIC Open Access Publication Support Initiative through its Unit of Information Resources for Research (URICI). AVA Biochem (Switzerland) is acknowledged for HMF supply.

\section{Authors' contributions}

MIS-R performed the experiments and wrote the first manuscript draft. AS designed and contributed to the experiments, and revised the results obtained. AS and ATM wrote the final version of the manuscript. All authors contributed to the discussion and conclusions obtained. All authors read and approved the final manuscript.

\section{Funding}

This work has been funded by the H2020 BBI-JU (https://www.bbi-europe.eu) EnzOx2 (H2020-BBI-PPP-2015-2-720297; https://www.enzox2.eu) project, the GENOBIOREF (BIO2017-86559-R) project of the Spanish Ministry of Science \& Innovation (co-financed by FEDER funds), the CSIC project PIE-201620E081, and the CSIC interdisciplinary platform for "Sustainable Plastics towards a Circular Economy" (SUSPLAST).

\section{Availability of data and materials}

All the data supporting the conclusions of this article are included within the article and its supporting information. Additional information can be provided by the corresponding authors under request.

\section{Declarations}

\section{Ethics approval and consent to participate}

Not applicable.

\section{Consent for publication}

Not applicable.

\section{Competing interests}

The authors declare that they have no competing interests.

Received: 3 May 2021 Accepted: 25 August 2021

Published online: 09 September 2021
References

1. Geyer R, Jambeck JR, Law KL. Production, use, and fate of all plastics ever made. Sci Adv. 2017;3:e1700782.

2. Gallezot P. Conversion of biomass to selected chemical products. Chem Soc Rev. 2012:41:1538-58.

3. Hwang KR, Jeon W, Lee SY, Kim MS, Park YK. Sustainable bioplastics: Recent progress in the production of bio-building blocks for the biobased next-generation polymer PEF. Chem Eng J. 2020;390:124636.

4. Loos K, Zhang R, Pereira IS, Agostinho B, Hu H, Maniar D, Sbirrazzuoli N, Silvestre AJD, Guigo N, Sousa AF. A perspective on PEF synthesis, properties, and end-life. Front Chem. 2020;8:585.

5. Papageorgiou GZ, Tsanaktsis V, Bikiaris DN. Synthesis of poly(ethylene furandicarboxylate) polyester using monomers derived from renewable resources: thermal behavior comparison with PET and PEN. Phys Chem Chem Phys. 2014;16:7946-58.

6. Burgess SK, Leisen JE, Kraftschik BE, Mubarak CR, Kriegel RM, Koros WJ. Chain mobility, thermal, and mechanical properties of poly(ethylene furanoate) compared to poly(ethylene terephthalate). Macromolecules. 2014;47:1383-91.

7. Rajesh RO, Pandey A, Binod P. Bioprocesses for the production of 2,5-furandicarboxylic acid. In: Varjani S, Binod P, Kumar S, Khare SK, editors. Biosynthetic technology and environmental challenges. Berlin: Springer; 2018.

8. Yuan H, Liu H, Du J, Liu K, Wang T, Liu L. Biocatalytic production of 2,5-furandicarboxylic acid: recent advances and future perspectives. Appl Microbiol Biotechnol. 2020;104:527-43.

9. Hu I, He AY, Liu XY, Xia J, Xu JX, Zhou SY, Xu JM. Biocatalytic transformation of 5-hydroxymethylfurfural into high-value derivatives: recent advances and future aspects. ACS Sustain Chem Eng. 2018;6:15915-35.

10. Saikia K, Rathankumar AK, Kumar PS, Varjani S, Nizar M, Lenin R, George J, Vaidyanathan VK. Recent advances in biotransformation of 5-hydroxymethylfurfural: challenges and future aspects. J Chem Technol Biotechnol. 2021. https://doi.org/10.1002/jctb.6670.

11. Sajid M, Zhao X, Liu D. Production of 2,5-furandicarboxylic acid (FDCA) from 5-hydroxymethylfurfural (HMF): recent progress focusing on the chemical-catalytic routes. Green Chem. 2018;20:5427-53.

12. Zhao D, Su T, Wang Y, Varma RS, Len C. Recent advances in catalytic oxidation of 5-hydroxymethylfurfural. Mol Catal. 2020;495:111133.

13. Domínguez de María P, Guajardo N. Biocatalytic valorization of furans: opportunities for inherently unstable substrates. Chemsuschem. 2017;10:4123-34

14. Troiano D, Orsat V, Dumont MJ. Status of biocatalysis in the production of 2,5-furandicarboxylic acid. ACS Catal. 2020;10:9145-69.

15. Lalanne L, Nyanhongo GS, Guebitz GM, Pellis A. Biotechnological production and high potential of furan-based renewable monomers and polymers. Biotechnol Adv. 2021;48:107707.

16. Carro J, Ferreira P, Rodríguez L, Prieto A, Serrano A, Balcells B, Ardá A, Jiménez-Barbero J, Gutiérrez A, Ullrich R, Hofrichter M, Martínez AT. 5-Hydroxymethylfurfural conversion by fungal aryl-alcohol oxidase and unspecific peroxygenase. FEBS J. 2015;282:3218-29.

17. Karich A, Kleeberg BS, Ullrich R, Hofrichter M. Enzymatic preparation of 2,5-furandicarboxylic acid (FDCA) - a substitute of terephthalic acid-by the joined action of three fungal enzymes. Microorganisms. 2018;6:5.

18. McKenna SM, Leimkuhler S, Herter S, Turner NJ, Carnell AJ. Enzyme cascade reactions: synthesis of furandicarboxylic acid (FDCA) and carboxylic acids using oxidases in tandem. Green Chem. 2015;17:3271-5.

19. Wu S, Liu Q, Tan H, Zhang F, Yin H. A novel 2,5-furandicarboxylic acid biosynthesis route from biomass-derived 5-hydroxymethylfurfural based on the consecutive enzyme reactions. Appl Biochem Biotechnol. 2020;191:1470-82

20. Qin YZ, Li YM, Zong MH, Wu H, Li N. Enzyme-catalyzed selective oxidation of 5-hydroxymethylfurfural (HMF) and separation of HMF and 2,5-diformylfuran using deep eutectic solvents. Green Chem. 2015;17:3718-22.

21. McKenna SM, Mines $P$, Law $P$, Kovacs-Schreiner K, Birmingham WR, Turner NJ, Leimkühler S, Carnell AJ. The continuous oxidation of HMF to FDCA and the immobilisation and stabilisation of periplasmic aldehyde oxidase (PaoABC). Green Chem. 2017;19:4660-5.

22. Jia HY, Zong MH, Zheng GW, Li N. One-pot enzyme cascade for controlled synthesis of furancarboxylic acids from 5-hydroxymethylfurfural by $\mathrm{H} 2 \mathrm{O} 2$ internal recycling. Chemsuschem. 2019;12:4764-8. 
23. Dijkman WP, Groothuis DE, Fraaije MW. Enzyme-catalyzed oxidation of 5-hydroxymethylfurfural to furan-2,5-dicarboxylic acid. Angew Chem. 2014;126:6633-6

24. Viñambres M, Espada M, Martínez AT, Serrano A. Screening and evaluation of new hydroxymethylfurfural oxidases for furandicarboxylic acid production. Appl Environ Microbiol. 2020;86:00842-920.

25. Serrano A, Calviño E, Carro J, Sánchez-Ruiz MI, Cañada FJ, Martínez AT. Complete oxidation of hydroxymethylfurfural to furandicarboxylic acid by aryl-alcohol oxidase. Biotechnol Biofuels. 2019;12:217.

26. Cavener DR. GMC oxidoreductases. A newly defined family of homologous proteins with diverse catalytic activities. J Mol Biol. 1992;223:811-4.

27. Dijkman WP, Fraaije MW. Discovery and characterization of a 5-hydroxymethylfurfural oxidase from Methylovorus sp strain MP688. Appl Environ Microbiol. 2014;80:1082-90.

28. Ruiz-Dueñas FJ, Ferreira P, Martínez MJ, Martínez AT. In vitro activation, purification, and characterization of Escherichia coli expressed arylalcohol oxidase, a unique $\mathrm{H}_{2} \mathrm{O}_{2}$-producing enzyme. Protein Express Purif. 2006:45:191-9.

29. Jankowski N, Koschorreck K, Urlacher VB. High-level expression of arylalcohol oxidase 2 from Pleurotus eryngii in Pichia pastoris for production of fragrances and bioactive precursors. Appl Microbiol Biotechnol. 2020;104:9205-18.

30. Román R, Loncar N, Casablancas A, Fraaije MW, Gonzalez G. High-level production of industrially relevant oxidases by a two-stage fed-batch approach: overcoming catabolite repression in arabinose-inducible Escherichia coli systems. Appl Microbiol Biotechnol. 2020;104:5337-45.

31. Dijkman WP, Binda C, Fraaije MW, Mattevi A. Structure-based enzyme tailoring of 5-hydroxymethylfurfural oxidase. ACS Catal. 2015;5:1833-9.

32. Martin C, Ovalle Maqueo A, Wijma HJ, Fraaije MW. Creating a more robust 5-hydroxymethylfurfural oxidase by combining computational predictions with a novel effective library design. Biotechnol Biofuels. 2018;11:56.

33. Rounds SA, Wilde FD, Ritz GF: Dissolved oxygen (ver. 3.0).U.S. Geological Survey Techniques of WaterResources Investigations, book 9, chap. A6, sec. 6.2. 2013. https://doi.org/10.3133/tm9A6.2.
34. Gemoets HPL, Su Y, Shang M, Hessel V, Luque R, Noël T. Liquid phase oxidation chemistry in continuous-flow microreactors. Chem Soc Rev. 2016:45:83-117.

35. Tamborini L, Fernandes P, Paradisi F, Molinari F. Flow bioreactors as complementary tools for biocatalytic process intensification. Trends Biotechnol. 2018;36:73-88.

36. Gasparini G, Archer I, Jones E, Ashe R. Scaling up biocatalysis reactions in flow reactors. Org Process Res Dev. 2012;16:1013-6.

37. Jones E, McClean K, Housden S, Gasparini G, Archer I. Biocatalytic oxidase: batch to continuous. Chem Eng Res Des. 2012;90:726-31.

38. Ringborg RH, Pedersen AT, Woodley JM. Automated determination of oxygen-dependent enzyme kinetics in a tube-in-tube flow reactor. ChemCatChem. 2017;9:3285-8.

39. Pedersen AT, de Carvalho TM, Sutherland E, Rehn G, Ashe R, Woodley JM. Characterization of a continuous agitated cell reactor for oxygen dependent biocatalysis. Biotechnol Bioeng. 2017;114:1222-30.

40. van Schie MMCH, Pedroso de Almeida T, Laudadio G, Tieves F, Fernández-

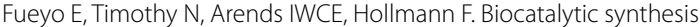
of the Green Note trans-2-hexenal in a continuous-flow microreactor. Beilstein J Org Chem. 2018;14:697-703.

41. Schmid A, Dordick JS, Hauer B, Kiener A, Wubbolts M, Witholt B. Industrial biocatalysis today and tomorrow. Nature. 2001;409:258-68.

42. Macheroux P. UV-visible spectroscopy as a tool to study flavoproteins. In: Chapman SK, Reid GA, editors. Flavoprotein protocols. Totowa: Humana Press; 1999. p. 1-7.

\section{Publisher's Note}

Springer Nature remains neutral with regard to jurisdictional claims in published maps and institutional affiliations.
Ready to submit your research? Choose BMC and benefit from:

- fast, convenient online submission

- thorough peer review by experienced researchers in your field

- rapid publication on acceptance

- support for research data, including large and complex data types

- gold Open Access which fosters wider collaboration and increased citations

- maximum visibility for your research: over $100 \mathrm{M}$ website views per year

At BMC, research is always in progress.

Learn more biomedcentral.com/submissions 